\title{
Article \\ A Qualitative Study of Female Migrant Domestic Workers' Experiences of and Responses to Work-Based Sexual Violence in Cyprus
}

\author{
Christiana Kouta ${ }^{1, *(1)}$, Christalla Pithara ${ }^{2,3}$ (), Zoe Apostolidou ${ }^{1}$, Anna Zobnina ${ }^{4}$, Josie Christodoulou ${ }^{4}$, \\ Maria Papadakaki ${ }^{5}$ and Joannes Chliaoutakis ${ }^{5}$ (D)
}

1 Department of Nursing, School of Health Sciences, Cyprus University of Technology, Limassol 3036, Cyprus; zoechristina@hotmail.com

2 Population Health Sciences, Bristol Medical School, University of Bristol, Bristol BS8 2PS, UK; christalla.pithara@bristol.ac.uk

3 National Institute for Health Research Applied Research Collaboration West, University Hospitals Bristol and Weston Foundation Trust, Bristol BS1 2NT, UK

4 Meditteranean Institute of Gender Studies, 46 Makedonitissas Avenue, Box 24005, Nicosia 1703, Cyprus; anna@migrantwomennetwork.org (A.Z.); jchristodoulou@mfa.gov.cy (J.C.)

5 Department of Social Work, School of Health Sciences, Hellenic Mediterranean University, 71004 Heraklion, Greece; mpapadakaki@hmu.gr (M.P.); jchlia@staff.teicrete.gr (J.C.)

* Correspondence: christiana.kouta@cut.ac.cy

check for updates

Citation: Kouta, C.; Pithara, C.; Apostolidou, Z.; Zobnina, A.; Christodoulou, J.; Papadakaki, M.; Chliaoutakis, J. A Qualitative Study of Female Migrant Domestic Workers' Experiences of and Responses to Work-Based Sexual Violence in Cyprus. Sexes 2021, 2, 315-330. https://doi.org/10.3390/sexes2030025

Academic Editors: Joana Carvalho and David Rowland

Received: 14 May 2021

Accepted: 25 June 2021

Published: 7 July 2021

Publisher's Note: MDPI stays neutral with regard to jurisdictional claims in published maps and institutional affiliations.

Copyright: (c) 2021 by the authors. Licensee MDPI, Basel, Switzerland. This article is an open access article distributed under the terms and conditions of the Creative Commons Attribution (CC BY) license (https:/ / creativecommons.org/licenses/by/ $4.0 /)$.

\begin{abstract}
Domestic workers face increased risk for sexual harassment and assault in the workplace but are often reluctant to disclose abuse or seek retribution. We report on a study looking at migrant domestic workers' responses to sexual violence, reasons behind their responses, and factors enhancing or diminishing vulnerability to abuse. We carried out qualitative, in-depth, individual and group interviews with 15 female domestic workers from the Philippines and Sri Lanka working in the Republic of Cyprus. Descriptive thematic analysis was used to analyse data using QSR NVivo 10.0. Sexual violence against migrant domestic workers was reported to be rampant, particularly among women living with their employer. Perpetrators took advantage of women's precarious legal, social, and economic circumstances to coerce women into a sexual relationship. All participants reported taking action to stop attacks despite the significant barriers they faced: racism and discrimination, social isolation, and hostile legal, labour, and immigration systems. Fear of losing their job, being deported, and facing racism and discrimination from the police were the biggest barriers to seeking retribution. Access to informational, e.g., legal, practical, and emotional support, facilitated positive outcomes following abuse, such as finding a new employer. Systemic racism, hostile labour and immigration systems, and lack of support increase risk of sexual violence and place barriers against accessing safe working spaces, protection, and justice. Women need to be informed of the risks involved in domestic work and empowered to identify abuse and access help and support when needed.
\end{abstract}

Keywords: migrant women; domestic work; sexual harassment; sexual violence; empowerment

\section{Introduction}

The term "domestic worker" is used to describe any person engaged in paid domestic work, whether for one or more households, regardless of their immigration status [1]. This work may involve jobs such as cooking, washing, ironing, and cleaning, and includes gardeners, care workers, and those on an au pair visa who are, in reality, domestic workers [2]. Migrant women are often engaged in domestic work, and the International Labour Organisation (ILO) estimates that in 2013, there were about 11.5 million migrant domestic workers worldwide, with about $73.4 \%$ of these being female third-country nationals [3]. 
Even though domestic work can be an empowering occupation for migrant women, allowing for autonomy and flexibility in organizing one's own working patterns, it can also be precarious. The ILO, in its convention No.189, "Decent Work for Domestic Workers", states "domestic work continues to be undervalued and invisible and is mainly carried out by women and girls, many of whom are migrants or members of disadvantaged communities and who are particularly vulnerable to discrimination in respect of conditions of employment and of work and to other abuses of human rights" [1].

The Human Rights Watch, among others, has reported on domestic workers' exploitative working conditions, with excessively long and often unpaid hours of work, restrictions on freedom of movement, and contact with others [4,5] in what Jureidini and Moukarbel aptly describe as "contract slavery" [6]. In the literature, authors have reported on the increased risk for abuse faced by domestic workers (e.g., [7-9]), whilst the sexualised nature of domestic work, the heightened power imbalance between employer and employee, and the confinement of work within the private sphere places women at particular risk for workplace sexual harassment and assaults [10-12]. A high incidence of sexual harassment is reported among domestic workers, especially those living in their employer's residence [11]. Despite the high incidence of sexual harassment and violence, women are often unwilling to report assaults [9]. Reasons include fear of ridicule, further stigmatisation, fear of retaliation and not finding other employment [11], lack of information of where to get help and support, and geographical barriers in accessing such help [13].

Domestic workers have been routinely portrayed in the literature as powerless victims of circumstance in a way that denies them agency $[12,14]$, whilst at the same time, domestic work and migrant women at risk of marginalisation, as is the case with migrant domestic workers, are often excluded from interventions aiming to empower women in dealing with sexual harassment in the workplace [15]. More understanding is needed of how these women express their agency in the context of (or despite) discrimination, structural inequalities [14], and human rights violations and what needs to be in place to support women in responding to sexual violence in the workplace in ways that empower them to achieve their own goals and objectives.

Lena Nare [14] tried to explore agency using a capability approach lens and discussed agency as a continuum of different capabilities, looking at what migrant women are able to do, i.e., the opportunities available to them along their migratory journey in order to achieve their long-term life goals. We adopt the same lens to help us understand women's experiences of work-based sexual violence against Asian women employed as domestic workers in the Republic of Cyprus between 2013 and 2014.

Our study aims to understand women's experiences of sexual harassment and assaults in the workplace-from now on referred to as sexual violence-, how women respond to such assaults, and the factors shaping their responses and agency. The questions asked include: (1) How do women respond to instances of verbal or physical sexual violence in all its forms and manifestations? (2) What are the factors that shape their decision-making and actions taken? And (3) What are the outcomes of these actions?

\section{Methods}

\subsection{Setting}

This study took place in the Republic of Cyprus (henceforth referred to as Cyprus). The large majority of domestic workers in Cyprus are immigrant women from the Philippines, Vietnam, and Sri Lanka [16,17]. An overview of the current legal and employment status of migrant domestic workers in Cyprus was given by Nasia Hadjigeorgiou [8].

The study was conducted as part of Commun-AID, a DAPHNE III EU funded project that aimed to address the under-explored phenomenon of sexual violence against migrant women working as domestic workers in the EU. The background to the study and additional findings have been published previously [15]. 


\subsection{Study Design and Sample}

In-depth, face-to-face interviews were conducted with immigrant women working in Cyprus as domestic workers either full-time or part-time and who self-identified as victims of sexual violence in the workplace. Because of the difficulties in recruiting women who themselves were victims of sexual violence, inclusion criteria were broadened to include women with second-hand experience, i.e., reporting experiences of friends or acquaintances. In this article, we use the term sexual violence to refer to "a sexual act that is committed or attempted by another person without freely given consent of the victim or against someone who is unable to consent or refuse" using, among others, intimidation, pressure, or misuse of authority $[18,19]$. It includes contact and non-contact acts, and for our purposes, it also includes acts of sexual harassment, the term most often used to refer to unwanted sexual acts committed in the workplace [19]. A qualitative descriptive design was used because of its ability to provide "a rich, straight description of an experience or an event" ([20], p. 2).

\subsection{Participant Recruitment}

Recruitment followed a purposeful snowball sampling strategy. Women were approached through organisations working with migrant domestic workers and through the researchers' own contacts (Filipino domestic workers acting as leaders within this community). Researchers made consecutive visits to organisations and places frequented by migrant domestic workers, including church support organisations, parks frequented during the women's day off, and approached contacts known by the researchers through previous research activities. Very early on, through these scouting activities, it was realized that recruiting women from Vietnam (one of the top three countries of origin for migrant domestic workers) would be particularly challenging because of language issues and lack of points of contact with key individuals from the community. Because of the time limitations inherent in the study, recruitment focused on women from the Philippines and Sri Lanka because it was easier to access these communities, and women were more likely to understand or speak English. Written information regarding the Commun-AID project was disseminated through information leaflets in English, Sinhalese, and Tagalog. Those expressing an interest to take part were offered more detailed information about the interview process and were informed about the voluntary and confidential nature of participation. All women who were approached were asked to refer other women who might be willing to talk to the researchers about their experiences. On the day of the interview, participants were informed about the purpose of the study, and researchers answered questions and addressed concerns before participants formally consented to take part in the study by completing an informed consent form. Recruitment was guided by the time limitations of the study, i.e., recruitment stopped at a pre-defined deadline, and the concept of "information power" [21], whereby recruitment targeted participants highly specific for the study aim, i.e., with in-depth knowledge of the focus of the study.

\subsection{Data Collection}

Interviews were conducted between April 2013 and April 2014 by three experienced qualitative researchers (C.P., Z.A., A.Z.). A topic guide (Supplementary Material File S1) was developed guided by the aims of the study exploring the following: women's experiences with domestic work and experiences of sexual violence in the workplace; women's responses to sexual violence, including coping strategies and access to support networks; the impact of sexual violence on women's lives; perceived needs for support, including barriers and facilitators to accessing help; and perceived needs of migrant domestic workers.

Interviews took place somewhere familiar to the participants to ensure women felt at ease (e.g., church premises, cafes, or parks). Interviews were conducted in English, but where group interviews were conducted, participants in some cases acted as impromptu interpreters for each other. Interviewers took detailed field notes, which were used as data 
and informed the transcribing of interviews. Interviews lasted between 20 and $120 \mathrm{~min}$. All interviews were audio-recorded using an encrypted digital audio recorder, and audio files were fully transcribed, anonymized, and checked for accuracy.

\subsection{Qualitative Data Analysis}

Anonymised interview transcripts were imported into QSR Nvivo data management software (QSR International, Version 10.0) (QSR International Pty Ltd., Melbourne, Australia) and analysed using thematic analysis [22]. Interview data were initially coded deductively, guided by the aims of the study and the themes covered during the interview. Further codes were inductively created within these initial categories during subsequent iterative rounds of analysis to reflect the issues spontaneously raised by participants during the discussion, which were subsequently categorised under higher order themes. Two researchers independently analysed transcripts (C.P. and A.Z.), with researchers meeting regularly to discuss emerging themes and agreeing on the final coding framework. The team met regularly to discuss ongoing analysis and emerging themes to ensure trustworthiness, credibility, and rigour.

\subsection{Ethical Considerations}

Participation was confidential and voluntary. Participants were offered a participant information leaflet in English as well as Sinhalese and Tagalog and were informed of the purpose of the study, its confidential and anonymous nature, and their right to withdraw at any stage. All participants were given an option as to where the interviews took place and to be accompanied by a friend to ensure a sense of safety as well as privacy. Pseudonyms are used to safeguard anonymity. Participants signed an informed consent for their participation. Because of the nature of the subject of the interviews, a list of services and organisations providing emotional, legal, or other practical support to migrant women was prepared and provided to all participants at the end of the interview.

\section{Results}

\subsection{Participants}

Interviews with 16 women took place; during the interview, one woman disclosed she was sexually abused by her partner, thus not fulfilling the inclusion criteria, and her transcript is not included in this paper; transcripts from interviews with 15 women are thus included in this report. Three women spoke about other women's experiences. Table 1 presents socio-demographic information for all 15 women (pseudonyms are used for all participants). The majority of women were from the Philippines $(n=13)$, and two were from Sri Lanka. Participants were between 26 and 53 years of age (average age $=43$ ). The majority (nine participants) were under 40 years of age.

Table 1. Participant demographic information.

\begin{tabular}{|c|c|c|c|c|c|c|c|c|c|c|}
\hline Pseudonym & Age & $\begin{array}{l}\text { Family } \\
\text { Status }\end{array}$ & $\begin{array}{l}\text { Harassment } \\
\text { Experience }\end{array}$ & Children & Origin & Education & $\begin{array}{l}\text { Residence at } \\
\text { Time of Abuse }\end{array}$ & $\begin{array}{l}\text { Number of } \\
\text { Years in } \\
\text { Cyprus }\end{array}$ & $\begin{array}{l}\text { Domestic Work } \\
\text { Experience Prior } \\
\text { to Arriving } \\
\text { in Cyprus }\end{array}$ & $\begin{array}{c}\text { Work } \\
\text { Situation }\end{array}$ \\
\hline Abigail & 29 & Single & $\begin{array}{l}\text { Self- } \\
\text { reported }\end{array}$ & 0 & Philippines & $\mathrm{N} / \mathrm{A}$ & Employer & 3 months & $\mathrm{N} / \mathrm{A}$ & Full time \\
\hline Betty & 33 & Separated & $\begin{array}{l}\text { Self- } \\
\text { reported }\end{array}$ & 2 & Philippines & $\mathrm{N} / \mathrm{A}$ & Employer & 11 months & $\mathrm{N} / \mathrm{A}$ & Full time \\
\hline Charlotte & 35 & Single & $\begin{array}{l}\text { Self- } \\
\text { reported }\end{array}$ & 0 & Philippines & University & Employer & $\begin{array}{l}3 \text { months } \\
18 \text { March } \\
2013\end{array}$ & $\begin{array}{l}\text { Worked in } \\
\text { Hong Kong } \\
\text { before }\end{array}$ & Full time \\
\hline Doris & 44 & Married & $\begin{array}{l}\text { Self- } \\
\text { reported }\end{array}$ & 3 & Sri Lanka & $\begin{array}{l}\text { Secondary } \\
\text { school }\end{array}$ & Employer & $\begin{array}{l}5 \text { March } \\
2013\end{array}$ & $\begin{array}{l}\text { Worked in } \\
\text { Jordan for } \\
2 \text { years }\end{array}$ & Full time \\
\hline
\end{tabular}


Table 1. Cont.

\begin{tabular}{|c|c|c|c|c|c|c|c|c|c|c|}
\hline Pseudonym & Age & $\begin{array}{l}\text { Family } \\
\text { Status }\end{array}$ & $\begin{array}{l}\text { Harassment } \\
\text { Experience }\end{array}$ & Children & Origin & Education & $\begin{array}{l}\text { Residence at } \\
\text { Time of Abuse }\end{array}$ & $\begin{array}{l}\text { Number of } \\
\text { Years in } \\
\text { Cyprus }\end{array}$ & $\begin{array}{l}\text { Domestic Work } \\
\text { Experience Prior } \\
\text { to Arriving } \\
\text { in Cyprus }\end{array}$ & $\begin{array}{c}\text { Work } \\
\text { Situation }\end{array}$ \\
\hline Evelyn & 31 & Married & $\begin{array}{l}\text { Self- } \\
\text { reported }\end{array}$ & 5 & Philippines & College & Employer & 3 years & $\begin{array}{l}\text { Worked in } \\
\text { Denmark }\end{array}$ & $\begin{array}{l}\text { Part time; } \\
\text { started on } \\
\text { full-time } \\
\text { contract }\end{array}$ \\
\hline Fiona & 46 & $\begin{array}{l}\text { Live-in } \\
\text { partner }\end{array}$ & $\begin{array}{l}\text { Self- } \\
\text { reported }\end{array}$ & 3 & Philippines & College & $\mathrm{n} / \mathrm{a}$ & 8 years & 8 & Part time \\
\hline Hayley & 44 & Single & Other's & 2 & Philippines & $\mathrm{N} / \mathrm{A}$ & $\begin{array}{c}\text { Self- } \\
\text { accommodation }\end{array}$ & 10 & $\mathrm{~N} / \mathrm{A}$ & Part time \\
\hline Iris & 38 & Partner & Other's & 0 & Philippines & College & $\begin{array}{c}\text { Self- } \\
\text { accommodation }\end{array}$ & 6 & $\mathrm{~N} / \mathrm{A}$ & Part time \\
\hline Joyce & 31 & Married & $\begin{array}{l}\text { Self- } \\
\text { reported }\end{array}$ & 3 & Philippines & $\mathrm{N} / \mathrm{A}$ & Employer & $\mathrm{N} / \mathrm{A}$ & Cyprus only & Full time \\
\hline Kate & 27 & Single & $\begin{array}{c}\text { Self- } \\
\text { reported }\end{array}$ & 0 & Philippines & $\mathrm{N} / \mathrm{A}$ & Employer & 1 & $\mathrm{~N} / \mathrm{A}$ & Full time \\
\hline Leila & 32 & Married & $\begin{array}{l}\text { Self- } \\
\text { reported }\end{array}$ & 1 & Philippines & $\mathrm{N} / \mathrm{A}$ & $\mathrm{n} / \mathrm{a}$ & 2.5 & $\begin{array}{l}\text { Previously } \\
\text { Hong Hong- } \\
7 \text { years }\end{array}$ & Full time \\
\hline Monica & 43 & Divorced & $\begin{array}{l}\text { Self- } \\
\text { reported }\end{array}$ & 3 & Philippines & $\mathrm{N} / \mathrm{A}$ & Employer & 3 & $\mathrm{~N} / \mathrm{A}$ & $\mathrm{N} / \mathrm{A}$ \\
\hline Noreen & 47 & $\mathrm{~N} / \mathrm{A}$ & Other's & 0 & Philippines & $\mathrm{N} / \mathrm{A}$ & $\begin{array}{c}\text { Self- } \\
\text { accommodation }\end{array}$ & 10 & $\mathrm{~N} / \mathrm{A}$ & $\mathrm{N} / \mathrm{A}$ \\
\hline Ophelia & 53 & Married & $\begin{array}{l}\text { Self- } \\
\text { reported }\end{array}$ & 0 & Sri Lanka & $\begin{array}{l}\text { High } \\
\text { school }\end{array}$ & Employer & 5.5 & 5.5 & Full time \\
\hline Page & 26 & Separated & $\begin{array}{l}\text { Self- } \\
\text { reported }\end{array}$ & 1 & Philippines & $\begin{array}{l}\text { High } \\
\text { school }\end{array}$ & Employer & 2 & Cyprus only & Full time \\
\hline
\end{tabular}

Five women were married, two had a partner, and the rest were either single or divorced/separated. The majority had children. Seven women reported their level of education, and over half of these reported having college- or university-level education, with the rest reporting to be high school/secondary school graduates. Participants reported working in Cyprus between three months and 10 years. Out of 13 participants reporting their type of employment, four reported working part time.

\section{Experiences of Sexual Violence}

All participants reported sexual harassment against migrant domestic workers in the workplace to be widespread. The majority of participants (11/15) reported experiencing multiple instances of sexual violence in the workplace, which, for the large majority, also included their living quarters. Two participants reported being raped, while one instance of rape was reported by a participant recounting the experience of others. One participant was sexually assaulted by the Cypriot boyfriend of one of her Filipina friends who had befriended her and employed her as a cleaner on her day off, resulting in an unwanted pregnancy. He was reported to be an older man in his late 60s. The second participant was raped by the elderly man she was employed to care for a few days following her arrival in Cyprus. In most cases, abuse entailed verbal sexual harassment, offer of money in exchange of sexual favours, inappropriate touching, and indecent exposure. Table 2 describes participants' experiences of sexual violence.

Table 2. A description of the perpetrator and the assault suffered by victims.

\begin{tabular}{cccccc}
\hline & Perpetrator & Age & When & Occurrences & Type of Assault \\
\hline Abigail & Employer & $40 \mathrm{~s}$ & After arrival & Multiple & $\begin{array}{c}\text { Verbal harassment and } \\
\text { inappropriate touching }\end{array}$ \\
\hline Betty & Employer & Older man, 70s & After arrival & Once & rape \\
\hline
\end{tabular}


Table 2. Cont.

\begin{tabular}{|c|c|c|c|c|c|}
\hline & Perpetrator & Age & When & Occurrences & Type of Assault \\
\hline Charlotte & Employer & $60 \mathrm{~s}$ & After arrival & Multiple & $\begin{array}{l}\text { Inappropriate touching, } \\
\text { verbal harassment }\end{array}$ \\
\hline Doris & Employer & $70 s ?$ & After arrival & $\begin{array}{l}\text { Was there for } \\
3 \text { weeks }\end{array}$ & $\begin{array}{l}\text { Inappropriate touching, } \\
\text { verbal harassment }\end{array}$ \\
\hline Evelyn & Boyfriend of friend & Late $60 \mathrm{~s}$ & & Once & Rape resulting in pregnancy \\
\hline Fiona & Employer & $\mathrm{N} / \mathrm{A}$ & $\begin{array}{l}\text { When wife was on } \\
\text { holiday (+1 year) }\end{array}$ & Once & Inappropriate touching \\
\hline Hayley & $\begin{array}{c}\text { Employers; } \\
\text { sons of employers }\end{array}$ & Mainly over 60 & $\begin{array}{l}\text { When wife is } \\
\text { not home; } \\
\text { during the night } \\
\text { when looking after } \\
\text { sick patients }\end{array}$ & Multiple & $\begin{array}{l}\text { Verbal harassment, } \\
\text { inappropriate touching, } \\
\text { forced sexual contact, rape }\end{array}$ \\
\hline Iris & Elderly employer & Over 60 & $\begin{array}{l}\text { While doing } \\
\text { housework }\end{array}$ & Multiple & $\begin{array}{l}\text { Verbal harassment, } \\
\text { inappropriate touching }\end{array}$ \\
\hline Joyce & Elderly employer & 76 & $\begin{array}{l}\text { Started when met to } \\
\text { sign contract and } \\
\text { was persistent }\end{array}$ & Multiple & $\begin{array}{l}\text { Verbal harassment, } \\
\text { inappropriate touching }\end{array}$ \\
\hline Kate & $\begin{array}{l}\text { Elderly father } \\
\text { of patient }\end{array}$ & 57 & $\begin{array}{l}\text { During nursing } \\
\text { of patient }\end{array}$ & Twice & $\begin{array}{l}\text { Verbal harassment, } \\
\text { inappropriate touching }\end{array}$ \\
\hline Leila & $\begin{array}{l}\text { Elderly father and } \\
\text { middle-aged } \\
\text { son-husband of } \\
\text { employer }\end{array}$ & $\mathrm{N} / \mathrm{A}$ & Constant & Multiple & Verbal harassment \\
\hline Monica & $\begin{array}{l}\text { Elderly husband of } \\
\text { employer }\end{array}$ & 61 & While asleep & $\begin{array}{c}\text { Once } \\
\text { (attempted rape); } \\
\text { multiple verbal } \\
\text { harassment }\end{array}$ & $\begin{array}{c}\text { Attempted rape; } \\
\text { inappropriate touching } \\
\text { precipitated or/and } \\
\text { followed the attempted rape }\end{array}$ \\
\hline \multirow[t]{2}{*}{ Noreen } & $\begin{array}{l}\text { 1. Husband of } \\
\text { employer }\end{array}$ & 50 & Constant & Multiple & $\begin{array}{c}\text { Verbal harassment } \\
\text { Attempted inappropriate } \\
\text { touching }\end{array}$ \\
\hline & $\begin{array}{l}\text { 2. Elderly husband } \\
\text { of employer }\end{array}$ & 60 & $\begin{array}{l}\text { Constant, when } \\
\text { alone }\end{array}$ & Multiple & Verbal harassment \\
\hline \multirow[t]{2}{*}{ Ophelia } & $\begin{array}{l}\text { 1. Elderly } \\
\text { employer }\end{array}$ & 94 & Constant & Multiple & $\begin{array}{c}\text { Verbal harassment } \\
\text { Inappropriate touching } \\
\text { Exhibiting themselves to the } \\
\text { worker }\end{array}$ \\
\hline & $\begin{array}{l}\text { 2. Elderly } \\
\text { employer }\end{array}$ & 82 & Constant & Multiple & $\begin{array}{c}\text { Offering money in exchange } \\
\text { for sexual favours; verbal } \\
\text { harassment }\end{array}$ \\
\hline Page & Employer & $40 \mathrm{~s}$ & $\begin{array}{c}\text { Less than a } \\
\text { year after } \\
\text { commencing work }\end{array}$ & Multiple & $\begin{array}{l}\text { Verbal harassment, } \\
\text { inappropriate touching }\end{array}$ \\
\hline
\end{tabular}

\subsection{Findings}

\subsubsection{Responding to Sexual Violence}

Participants reported several ways in which they responded to sexual violence in the workplace: changing their own behaviour as a way of stopping abuse, reporting to family members of the perpetrator, going to the authorities and seeking retribution, seeking advice from friends and family, and in some cases, running away. Table 3 presents women's responses to sexual violence. 
Table 3. Information on the action taken by victims to deal with the assault.

\begin{tabular}{|c|c|c|c|}
\hline Code & 1st Disclosure & 2nd Disclosure & Action \\
\hline Abigail & Friend and parents in Philippines & Recruitment agency & Run away \\
\hline Betty & Filipina passing outside the house & Daughter of perpetrator & Run away \\
\hline Charlotte & Daughter of perpetrator & & Run away \\
\hline Doris & Daughter of perpetrator & & Run away \\
\hline Evelyn & Employer & & Go to police \\
\hline Fiona & No disclosure & & \\
\hline Hayley & Friends, community members & & No further action; police \\
\hline Iris & Daughter of employer & Friend & $\begin{array}{l}\text { First did nothing; when situation } \\
\text { escalated, ran away }\end{array}$ \\
\hline Joyce & Daughter of employer & $\begin{array}{l}\text { Migrant worker organisation and } \\
\text { immigration/labour departments }\end{array}$ & $\begin{array}{l}\text { Formal complaint with immigration } \\
\text { and labour department }\end{array}$ \\
\hline Kate & Close friend & Husband of patient & Perpetrator stopped \\
\hline Leila & Friends & $\begin{array}{l}\text { Daughter-in-law of perpetrator, son } \\
\text { of perpetrator }\end{array}$ & Ongoing \\
\hline Monica & Co-employer & Wife of perpetrator & $\begin{array}{l}\text { Asked for and received release } \\
\text { paper from employer without filing } \\
\text { a formal complaint }\end{array}$ \\
\hline Noreen & Friends; people from church & Immigration office; friends & $\begin{array}{l}\text { Complaint with police; } \\
\text { run away }\end{array}$ \\
\hline Ophelia & Daughters of perpetrator both time & & $\begin{array}{l}\text { Release paper both times, no } \\
\text { police report }\end{array}$ \\
\hline Page & Friends & & $\begin{array}{c}\text { On-going } \\
\text { Is considering asking for release } \\
\text { paper directly from employer }\end{array}$ \\
\hline
\end{tabular}

\section{Choosing Non-Confrontational Ways to Stop Sexual Violence}

Women did not always feel immediately alarmed by the perpetrator's behaviour nor interpreted assaults as sexual violence. In cases where sexual harassment was described as subtle and covert, women tried to control the situation by attempting to convey the message to the perpetrator that they were not open to sexual advances in a non-confrontational manner. Avoiding being alone with the perpetrator, subtly refusing advances, and changing their own behaviour were, in some cases, responses intended to stop harassment.

I just wear the jogging pants, I don't wear the tights or anything [more attractive, I wear clothes that] have chlorine on them or something like that. (Leila; Philippines)

Distrust towards Cypriot society in general and those in positions of authority more specifically acted as a deterrent to disclosure, as women expected their reports to be dismissed without any efforts made to bring the perpetrator to justice.

(Victims) they just be silent and work for another employer, because they think justice here is I don't know ... there is no justice here especially in Cyprus [ ... ]. We are the victims, so instead of giving us opportunity and believing us and trust us why some of the Cypriot people they don't believe us, instead "oh go back to the Philippines", they don't care. (Abigail; Philippines)

Fear of losing their employment and residence visas was another reason women were hesitant about disclosing their abuse. Migrant women domestic workers are in a precarious financial situation exacerbated by the cost incurred in the process of finding employment abroad. Recruitment agencies in both their country of origin and destination country charge women high fees to secure domestic work contracts funded through loans. Financial insecurity and debts along with the residency permit requirements act as a barrier to disclosure. 
(I depend on my job) to pay all the things, the money to the agent in Philippines [ ... ] it is about 1200 euro. [ ... ]. Every month they take 50 euro from my salary to cover this. (Joyce; Philippines)

I am still quiet because I am always thinking about my debt in the Philippines, because when I came here I borrowed money from the bank in the Philippines, it's around 3000 euros from the bank so I need to pay it back. (Abigail; Philippines)

In the case of our participants, non-confrontational strategies did not deter perpetrators, and often assaults escalated to a point where women realised their safety might be in danger.

I am the kind of person, I don't like too much problems. Whenever I go work with them, I can ignore the things. [ ... ]. But slowly-slowly, as what he was doing, everything about what he wants, that he likes me, and this of course it gives me a little fear. (Joyce; Philippines)

When women realised their safety was in danger, then efforts to make such attacks stop were escalated.

Turning to the Family of the Perpetrator

In several cases, women acted by disclosing their attacks to female members of the employer's household, who, in most cases, were reported to normalise and trivialise the attacks and were not always willing to stop the abuse.

(After disclosing to the female employer her father-in-law's attempt to inappropriately touch the participant) my lady-boss, she said "I don't believe that my father-in-law makes like that to you. He is a very good man. He is just asking that he did like this to you. He is just trying, if he touched you, to see if you say 'yes'". (Leila; Philippines)

In some cases, steps were taken by family members to protect workers, but women were still expected to remain silent about the assaults and continue in their current role despite the seriousness of the attacks. In the following excerpt, the worker is accused and blamed by the perpetrator's daughter for leaving the house of her employer despite being raped by him.

(The perpetrator's) daughter came into the house and said, "are you ok?" [ . . ] and then I told her the story of what happened of what her father did to me, and then she said, "is that really true?" [..] and then after five days [... ] put the lock on my room, on the toilet, on my washing room, and then they said to me, "don't tell it to your agent" [ . . . ] (the daughter) saw me I'm fixing my things, "what's that?" [ . . ] "are you leaving? Are you going to do that to us? We even let you go to the doctor, to check you up to give you medicine, you will do that to us?" (Betty; Philippines)

\section{Recruitment Agencies}

Recruitment agencies were described to be friends of the employer and part of the Cypriot mainstream and thus not trusted to help protect women. In the same way as family members, recruitment agents dismissed women's reports without offering any meaningful support. In most cases, women were advised to return to their duties and the agencies tried to disrepute and disprove women's stories, trying to scare women into silence by arguing their story would not be believed by the police.

I also go to my agent I informed him [ ... ] maybe he can give me some advice [ ... .]. I don't know what to do, (I am) frightened, and he told me just go back to your employer, [...] if you make a lie we are in big problem [ . . ] and I think agent receive money from the employer they are together, so whatever I tell to him even that is true he doesn't believe me, because I am just a foreigner here. (Abigail; Philippines)

Making Formal Complaints to Authorities

In some cases, women turned to the authorities to make official complaints but reported being unfairly treated and their abuse disclosures to be dismissed. Only one 
participant reported taking the case to court, and she attributed this to a voice-recording of the perpetrator making sexual comments.

I: Do you think your record was important in solving your case?

J: Yes. Because in my complaint, I wrote that he was harassing me verbally, only verbally. And, who will believe me, that he can do this? My employer is 76 years old [ ... ]. Then part of my complaint I also write that I have a record that can justify my complaint, that I am telling the truth. So, this record plays a big role in my complaint. (Joyce; Philippines)

Police officers were reported to question the honesty of the reports, in some cases turning the blame on women's decision to refuse the perpetrator's advances.

And then (the policeman) said "Why did not you give massage to your employer? Just only massage. And you will get 100 Euro. And finish!" And they are laughing! (Joyce; Philippines)

One participant reported how police officers laughed when she told them she wanted to make a complaint for sexual harassment: "why did they laugh? Is sexual harassment funny?" (Doris; Philippines). Participants reported being intimidated by police officers and threatened that, in the absence of evidence and if they were found to be lying to the authorities, they would be jailed and deported. Lack of evidence was a tool used to inhibit women from making formal complaints.

In the police department they would always ask me "Do you have evidence? And I would always tell them "Sir, I would not come in the open, if these are my own lies. Although I don't have evidence, this is what happened to me. (Charlotte; Philippines)

[She complained to the police, but] nothing happened, the boss told the police, because the police went there in the house that you know this so and so made a complaint about you and like this .... (the perpetrator accused the worker) she was lying. (Noreen; Philippines)

Turning to Social Networks

In many cases, women were dependent on their own social networks for finding ways to deal with abuse. Social networks were instrumental in making new migrants aware of sexual violence in the workplace:

It was actually the other Filipina that I replaced who explained it to me [ . . . ] before she left she told me [...] that in such a case if my employer does something to me, you may call the immigration or police. (Charlotte; Philippines)

They were also helpful in helping women escape by running away from the employer's house and finding refuge:

I stayed with my employer one and a half months and I decided to leave the house, because when I asked for the release, he answered he would never agree to give me a release paper, and he would book me a ticket and would send me back to the Philippines. That is the reason why I leave the house and came here to the social center. [ ... I I need to protect myself. I need to prevent (rape). The earlier the better. (Leila; Philippines)

This help also extended to finding new employers:

Then I talk to my friends, and they helped me to find a new employer. And now I have a new employer. (Monica; Philippines)

Hayley, a Filipino leader among domestic workers, described her role and the role of the Filipino network in supporting women through sexual violence:

(Women first disclose their experiences) to a friend. Many times, I've been (approached by women to provide support). We go to a special place, you know. [ . . ] You know, many many cases. There is a network of friends. And you know, you can hear more of these stories more on days off, on Sunday. (Hayley; Philippines)

Some women who were practicing Christians were given contact details of church organisations by their pastors or priests in their country of origin or found a church upon their arrival, and this helped them to find support when they needed it. 
I am a born-again Christian so my pastora, she is the one who bring me to the social centre, my pastora here in Cyprus. Because when I came here, on my first day off, I find church so I meet someone and I am happy because she is also a Christian, and she bring me to their church. (Abigail; Philippines)

(The people who helped me) basically, we are strangers, but we meet, they helped me in the church, I came to the church, and they told me to stay there. And (they helped me) with legal things, and something like this. (Monica; Philippines)

Being isolated in the employer's house made it more difficult for women to access support. Women who were attacked very shortly after their arrival and who had not formed any social links with other women faced significant challenges in dealing with sexual violence. One participant who was raped during her first few days in her new job described how she waited outside her employer's house the day after the attack in case other Filipino women passed by to ask for help:

I don't know any Filipinas here, and then I remembered (the perpetrator's) daughter told me there are Filipinos walking around in front of the house going to their work, so in the morning I go in front of the house waiting for a Filipina to pass by there, and then I saw one and then I asked her "please help me". (Betty; Philippines)

Being dependent on acquaintances made in Cyprus could place women at risk from networks involved in human trafficking or sexual abuse of vulnerable migrant women. This was the experience of one participant who approached what she thought was a Filipino support organisation but which turned out to be involved in trafficking and exploitation of migrant women.

I feel very very helpless, really, especially at that time I don't know where to go, [ . . . ] what happened to me, I found a wrong organisation! A Cypriot man, and he (is in charge of what he calls) a Philippines association in Cyprus [...]. He is the one who encouraged me to come to Nicosia, he said he will help me, [ . . ] (but after contact with) the Philippines consulate, [ ... ] (they) told me why you went there? his organisation is not legal, go away from him, he will pursue you to be a prostitute. (Abigail; Philippines)

A small minority of women reported accessing their consul for help, and the majority of these did not report being supported in a substantial way.

\subsubsection{Factors of Vulnerability}

Vulnerability to sexual violence and women's perceived ability to protect themselves, escape a dangerous situation, and achieve retribution was impacted by several factors linked to women's gender, ethnicity and economic position as well as broader societal, legal, and structural ones.

Employment and Visa Legal Requirements

The rules surrounding employment contracts and the legal requirements for women to secure the necessary visa documents placed women under the control of employers and made them vulnerable to abuse and exploitation. As a way of controlling migrants' stay in Cyprus, there is a legal requirement for employers to pay a deposit intended to cover the worker's repatriation expenses after the end of employment, known as a bank guarantee. This fee is repaid to the employer when the worker returns to their country of origin or is employed by another employer after being formally released from the current contract. It is not refunded if workers do not return to their country of origin or if they leave their employer without securing alternative employment, thus becoming undocumented. Even though it can, in theory, protect the worker from having to pay the repatriation fee, it is often used by employers as a tool to control workers' behaviour. Joyce recounted asking for the release paper from her female employer after being attacked by the employer's father but was then refused because of the bank guarantee fee and fear of the perpetrator's reactions. 
(The daughter asked) "Ok. What do you want?" (following the worker's disclosure of the attack). "Ma'am, if it is possible, the release". [ . . . . Because he also told me that he would send me to the Philippines. Of course, I want to work! For my family. And the daughter told me "Ok, I will speak to my mom about this thing, what we need to do." [ . . ]. (The mother) said "Listen Joyce. We cannot give you release. Because my husband will get angry. If you want release, you have to pay first the bank guarantee." (Joyce; Philippines)

The bank guarantee was also used as a threat to intimidate women into submission and prevent them from reporting the perpetrator to the authorities: "He told me 'I paid $a$ lot of money for you to come here'" (Betty; Philippines). This was because it gave employers power to terminate employment and deport women without any liability.

(Some women are afraid to go the police) because some, you know, some bosses when they do it, of course the police will call the boss, the boss will tell (the police), send her home something like this because they are the one who give this bank guarantee. (Hayley; Philippines)

And you know what he said [when the participant refused advances]? It is up [to] him if he wants to continue the [employment] contract with me. (Joyce; Philippines)

One participant described how her employer took her passport, promising to return it only if she repaid the bank guarantee fee or acquiesce to a sexual relationship:

He told me "If you want your passport back, you have to pay your bank guarantee", because maybe I will leave. [ ... ] I told him "Sir, why should I leave? I need money, why should I leave?" "I don't trust you," he told me. Now I know why he was saying like this, but then ... because he wants something from me, but I cannot give it to him. (Joyce; Philippines)

Control of workers' movements by the employer is also facilitated by a clause in the employment contract that places responsibility on the employer for providing accommodation to the worker. Women are either offered a room in the employer's house or provided with living quarters in close proximity to the employer's house, e.g., in a granny annexe. This, however, gives employers $24 / 7$ access to workers and places them at increased risk for abuse. All participants reported being attacked in the house of the employers, which was also their residence.

(My employer) came to sleep in my bed [ . . . It happened four or five times but then I shouted. I went to the bathroom, I came back and he was in my bed. I said why are you in my room, go! I had my own room but he said not to lock the room. I locked the room after and he was angry. (Doris; Sri Lanka)

When I came here, I go straight to my employer house, [ . . ] in the evening [ . . ] (the employer) entered my room. [ ... ]. And we stayed in one house, my room is outside the house, but [ ... ] he has a duplicate, he uses the duplicate (key). (Charlotte; Philippines)

On my fourth day, (the employer) came to my room. The room has no lock, you close the door and has no lock. (Betty; Philippines)

Representations of Migrant Women Domestic Workers

All participants described a sexualised understanding of migrants, especially female Asian domestic workers, to be prevalent among employers and Cypriot society in general.

(My female employer) keeps on telling me "You are a prostitute. Did you even pass your school exam?" (Kate; Philippines)

Women resented such representations, as these contradicted their own moral identity:

Some people here, maybe you have someone like me, and they say, "Why you did not agree with this offer?" Why they are talking like that? [ . . ] they want me to ruin myself. (Monica; Philippines)

There was a shared expectation by male employers, particularly elderly men, that domestic work entailed sexual duties, in some cases viewing the worker as a substitute wife: 
He always told me that I should understand him, because he needs it physically, and he is alone. (Charlotte; Philippines)

He thought he got a new wife and not only a house worker! He said grandmother did before now you have to do. (Doris; Sri Lanka)

He told me that his wife, she had an operation. And she cannot do some sex with him. Like this. And I told him: "Sir, there are many girls there, you can pay for them". And he said "You are very lucky"(I am offering money for such arrangements). (Joyce; Philippines)

Perpetrators, in many cases, viewed domestic workers as prostitutes and expected women to be willing to accept money for sexual favours because of their precarious economic circumstances.

I said don't touch my body, but he said I will give you money to send to Sri Lanka. (Doris; Shri Lanka)

(The employer and I met to) speak about the contract, at the start he told me that "I like you. I will help you. I will give you another account, to put money there" like this. And he showed me what he wanted. And I said "Sir, it is not a part of my work! To give you massage [... ]. (The employer said) It is up to him if he wants to continue the contract with me. (Joyce; Philippines)

Access to Social and Informational Support

It was clear from the narratives that women were given little support before and after their migration that would enable them to deal with sexual violence in the workplace. Information and training received in their country of origin mainly focused around housework skills and how to meet the demands of the Cypriot employer, but no information was given on how to deal with difficulties in the workplace.

Before we come, we have the orientation, and they will tell us to go to the Philippines consulate, but they don't give us the number of the Philippines consulate or where is the consulate, the address we don't know that. (Betty; Philippines).

Even more importantly, women were thought to be lured into migration with promises of high earnings and good jobs, but the reality of the dangers of domestic work were not highlighted, leaving women unprepared to deal with abuse.

For me, the agency should say what is really going on here, they should not just fancy us about what Europe is, [ ... ] they should warn us to be careful with our own selves, especially with the old men, or if you are alone in your room, don't trust anyone or something like that, just to warn us, to make us alert. What to do, so that we won't be shocked, or if that thing will happen we can protect ourselves, [ ... ]. The agency in the Philippines should warn us. (Betty; Philippines).

\section{Discussion}

This paper reported on migrant women's responses to sexual violence attacks in their workplace and factors which facilitated or curtailed their agency. Few studies have focused on domestic workers' agency and responses to sexual violence [14], and our findings add to this literature by filling a gap in our understanding of women's experiences of sexual abuse, highlighting women's resilience as well as lack of support and opportunities allowing women to express their agency, change their circumstance, and thrive. Findings highlight the few avenues open to women allowing them to pursue their goals: primarily to remain in legal employment and continue to financially support their families in their country of origin but, at the same time, understand how the legal frameworks that regulate immigration and domestic work and transatlantic recruitment networks and processes as well as the specific Cyprus socio-cultural context that disempowers and limits women's agency and increases vulnerability and exploitation.

Our findings reflect other work reporting on the human rights violations against domestic workers in other countries (e.g., [11]), and we reiterate the call made by the ILO for 
the need for change in the legal frameworks governing domestic work $[23,24]$. Our findings also reflect recent work reporting on the state of migrant domestic work in Cyprus [8,25]. Employment and immigration visa requirements such as "tied visa" schemes and shared accommodation with employers increase women's vulnerability to sexual violence [26] and their ability to escape from dangerous situations and achieve retribution through controlling women's mobility and associations [4,7]. Legal frameworks [27], in combination with embedded social stereotypes, institutional racism, and discrimination $[17,28]$, made it almost impossible for women to find justice and retribution.

Nasia Hadjigeorgiou discusses how systemic and social factors specific to the context of Cyprus (i.e., the deprioritisation of the feminist agenda, the normalization of nationalist policies, and a skewed understanding of human rights) contribute to the especially dire situation of migrant domestic workers in Cyprus [29]. Domestic workers in Cyprus are often viewed as "Other", faced with racism and discrimination embedded in gender and ethnic connotations attributed to domestic work [30], reflecting findings from other cultural settings [31]. Research exploring the views of Cypriot society towards female migrant domestic workers has discussed how Cypriot households have expressed desires as to the ethnic background of their future domestic workers, preferring Asian women over Central and East Europeans based on stereotypical beliefs about the timid and unthreatening nature of Asian women [32]. This might explain why, in our participants' experiences, wives of perpetrators ignored the sexual nature of the perpetrator's contact with the worker even when they were witnesses to harassment. The idea of an "ideal live-in maid" has also been discussed in the context of other cultures [33]. Prodromos Panayiotopoulos discussed the way domestic workers who were prepared to assert their rights were accused of being "immoral", "ungrateful" and as exhibiting "criminal conduct" [34]. Refusals to obey employer demands have been reported to lead to accusations of inappropriate behaviour of the domestic worker, setting in motion processes of non-renewal or termination of contract [34].

Responding to sexual harassment was, in some cases, influenced by women's own understandings of what constitutes abuse. Sexual violence is not always easy to define and can be subject to varying interpretations and understandings that influence and shape how women react and respond to such incidences [26]. Ashvini Jayapalan and colleagues reported that women from Malay, Indian, and Chinese ethnic backgrounds differed in their understandings of what sexual violence is, with physically forced penetration being the most prevalent understanding [26]. These authors report participants viewed improper code, e.g., being dressed in "sexy ways" and being too attractive, as predisposing factors to sexual abuse. These beliefs were partly reflected in our study, where one way of deflecting sexual harassment was by dressing in what were thought to be non-provocative ways.

Despite these challenges, women in our study described the ways in which they managed to escape their employer, and even though the large majority did not achieve legal retribution, many managed to find other legal employment where they felt safe. The role of social networks, information, and awareness of women's employment rights and links to trusted sources of support is emphasised in our findings, as women were able to escape a precarious situation following advice from and communication with other domestic workers and identification of a support system that they thought would help them in finding new employers without being deported. The language barriers that we faced in our recruitment efforts, however, are also an indication of the communication barriers and risk for isolation that migrant domestic workers with limited literacy skills might face. Having no access to a safe haven means women may feel no way out but to run away, which could lead to trafficking, becoming undocumented, or other forms of exploitation [4].

Following advocacy on (the lack of) domestic worker's rights, the ILO [1] has stated that "domestic workers are neither 'servants', nor 'members of the family' nor second class workers" ([1], p. 4) and should enjoy the same rights and protections as other employees working in the formal economy. It is argued that these structural changes need to be 
supplemented by a perhaps more important community-based approach that addresses domestic worker's individual and collective capacity to act in cases of sexual violence in the workplace. The ILO convention highlights what governments, agencies, and organisations can do to safeguard domestic workers, including provision of training and increasing literacy-relevant skills among workers [1].

It is imperative to address and increase women's capacity for expressing agency. So far, research and training targeting sexual harassment in the workplace has not addressed the needs of women from racialized and marginalized groups despite the empowering role of education and information provision [35] and the increased risk these groups face for sexual abuse [15]. Workshops and information-provision sessions targeting migrant workers appear to focus on employment obligations and assimilation in the receiving culture or provide information on labour rights, social support, or access to services [36] but ignore the gendered aspect of domestic work. Gender-focused interventions that address sexual violence appear to focus on women in mainstream employment and target domestic violence but not the specificities faced by migrant female domestic workers [15].

Our study suffers from certain limitations and challenges. Despite efforts to recruit women from diverse ethnic groups, only women from the Philippines and Sri Lanka were represented in our study. Because of the isolation and invisibility of migrant domestic workers, there were significant challenges in recruitment. The need to provide a name on the consent form and the request to audio-record the interview acted as an additional barrier to participation because of fears of sharing details with the authorities and subsequent deportation. To address these, women had the option of signing with a pseudonym. The use of a snowball sampling technique might have limited participant diversity and the range of experiences captured in the study. Women from other ethnic groups, for example, Vietnam and Nepal, did not frequent the public spaces we had easy access to nor the migrant organisations we approached, making it difficult to make links with these communities; English language skills were also more limited within these groups, making it difficult to make links and conduct interviews without an interpreter. Time and budget limitations restricted our ability to employ interpreters, however.

The exploratory focus of the study, which aimed to understand the breadth of experiences with sexual violence within the target community rather than a phenomenological understanding of individual experience, made information power [21] an appropriate aim for recruitment, and the trust cultivated through women being recruited by members of their own community who they already knew made them more open to sharing personal and often traumatic experiences. Our reporting of the study followed the COREQ framework of reporting qualitative research [37].

\section{Conclusions}

Findings have shed light on the decisions women take following acts of sexual violence in the workplace and the kind of opportunities available to them allowing to express their agency. Empowering and disempowering practices and phenomena which influence these responses were also described. Our findings reflect both the Cypriot and international literature discussing the experience of domestic work by migrant women and the structural factors that (re)produce inequalities and exploitation $[4,12,25,38]$. It now becomes crucial to increase efforts to empower women and increase capacity for expressing agency. There is a need for empowering migrant domestic workers through training to increase women's awareness of sexual violence in the workplace and of their employment and immigration rights alongside any efforts to protect their human rights through policy and legal interventions $[15,17]$. Training interventions need to address the lack of information on where to turn to for help and of support to help them navigate government agencies including the police.

These findings, placed in the context of the broader literature, suggest the need for increasing and fostering women's agency to deal with the risk and incidence of sexual violence alongside the struggle for structural change. Empowerment programmes that 
encompass educational material, experiential workshops, and participatory approaches have been advocated as a way to address gender-based violence [35,39]. Our research highlights that key aspects of such programmes should incorporate options for taking action when faced with sexual violence, educating women on their legal rights as workers and as immigrants, understanding the special circumstances faced by domestic workers in the context of the legal frameworks that govern labour and immigration realities for this group, and information on government, NGO, voluntary, and community structures that women can access for support.

Supplementary Materials: The following are available online at https:/ /www.mdpi.com/article/10 $.3390 /$ sexes2030025/s1, File S1: Interview topic guide.

Author Contributions: Manuscript writing—original draft preparation: C.K. and C.P.; manuscript writing - review and editing: C.K. and C.P.; study conceptualization and funding acquisition: M.P., J.C. (Joannes Chliaoutakis), C.K. and J.C. (Josie Christodoulou); data collection and analysis: C.P., Z.A. and A.Z. All authors have read and agreed to the published version of the manuscript.

Funding: This research was funded by the European Commission under the DAPHNE III programme (Grant Agreement: JUST/2011/DAP/AG/3272).

Institutional Review Board Statement: The study was conducted according to the guidelines of the Declaration of Helsinki. We have followed the procedures required by the participating institutions and/or funding agent, we have explained any risks and/or benefits (verbally or in writing) to potential participants, participants verified in writing that they understood risks and benefits, and that participation was completely voluntary. Participation was anonymous and pseudonyms were used in all transcripts analyses and throughout the report of the findings.

Informed Consent Statement: Informed consent was obtained from all participants involved in the study.

Data Availability Statement: Data supporting results reported in this article can be provided by the authors upon request.

Acknowledgments: A special acknowledgement goes to the women who participated in this study and to Lissa Jataas for helping with recruitment and data collection. Christalla Pithara's time is supported by the National Institute for Health Research Applied Research Collaboration West (NIHR ARC West). At the time of the study, Christalla Pithara was a member of the Cyprus University of Technology and funded by that organization. Authors would like to thank all the members of the Commun-AID consortium.

Conflicts of Interest: The authors declare no conflict of interest.

\section{References}

1. International Labour Organisation. Convention No.189. Decent Work for Domestic Workers; International Labour Organisation: Geneva, Switzerland, 2011.

2. European Federation of Food Agriculture and Tourism Trade Unions. Promote Industrial Relations in the Domestic Work Sector in Europe; European Federation of food Agriculture and Tourism Trade Unions: Brussels, Belgium, 2015.

3. International Labour Organisation. Global Estimates of Migrant Workers and Migrant Domestic Workers: Results and Methodolog; ILO: Geneva, Switzerland, 2015.

4. Human Rights Watch. Hidden Away: Abuses against migrant Domestic Workers in the UK; Human Rights Watch: New York, NY, USA, 2014.

5. Human Rights Watch. Slow Reform: Protection of Migrant Domestic Workers in Asia and the Middle East; Human Rights Watch: New York, NY, USA, 2010.

6. Jureidini, R.; Moukarbel, N. Female Sri Lankan domestic workers in Lebanon: A case of "contract slavery"? J. Ethn. Migr. Stud. 2004, 30, 581-607. [CrossRef]

7. Pavlou, V. Migrant domestic workers, vulnerability and the law: Immigration and employment laws in Cyprus and Spain. Investig. Fem. 2016, 7, 149-168. [CrossRef]

8. Hadjigeorgiou, N. Report on the Status of Foreign Domestic Workers in Cyprus. Available online: https:/ / equineteurope.org/20 21/cyprus-report-on-the-status-of-foreign-domestic-workers / (accessed on 8 January 2021).

9. Figueiredo, M.d.C.; Suleman, F.; Botelho, M.D.C. Workplace Abuse and Harassment: The Vulnerability of Informal and Migrant Domestic Workers in Portugal. Soc. Policy Soc. 2018, 17, 65-85. [CrossRef] 
10. Anderson, B. Doing the Dirty Work? The Global Politics of Domestic Labour; Palgrave Macmillan: London, UK, 2000.

11. DeSouza, E.R.; Cerqueira, E. From the Kitchen to the Bedroom: Frequency Rates and Consequences of Sexual Harassment Among Female Domestic Workers in Brazil. J. Interpers. Violence 2009, 24, 1264-1284. [CrossRef]

12. Saldaña-Tejeda, A. Tlazolteotl: 'The Filth Deity' and the sexualization of paid domestic workers in Mexico. Sexualities 2014, 17, 194-212. [CrossRef]

13. Kristen, E.; Banuelos, B.; Urban, D. Workplace violence and harassment of low-wage workers. Berkeley J. Employ. Labor Law 2015, 36, 169-204.

14. Näre, L. Agency as capabilities: Ukrainian women's narratives of social change and mobility. Women's Stud. Int. Forum 2014, 47, 223-231. [CrossRef]

15. Kouta, C.; Pithara, C.; Zobnina, A.; Apostolidou, Z.; Christodoulou, J.; Papadakaki, M.; Chliaoutakis, J. A systematic review of training interventions addressing sexual violence against marginalized at-risk groups of women. Health Educ. Res. 2015, 30, 971-984. [CrossRef] [PubMed]

16. CYSTAT. Labour Force Survey 1999-2017; Cyprus Statistical Service: Nicosia, Cyprus, 2018.

17. Christodoulou, J.; Zobnina, A. Investigating Trafficking in Women for Labour Exploitation in Domestic Work: The Case of Cyprus. In "I Thought I Was Applying as A Care Giver", Combating Trafficking in Women for Labour Exploitation in Domestic Work; University of Nicosia Press: Nicosia, Cyprus, 2015; p. 27.

18. Centre for Disease Control and Prevention. Sexual Violence. Available online: https://www.cdc.gov/violenceprevention/ sexualviolence/index.html (accessed on 17 January 2019).

19. Basile, K.C.; Smith, S.G.; Walters, M.L.; Fowler, D.N.; Hawk, K.; Hamburger, M.E. Sexual Violence Victimization and Associations with Health in a Community Sample of Hispanic Women. J. Ethn. Cult. Divers. Soc. Work. 2015, 24, 1-17. [CrossRef]

20. Neergaard, M.; Olesen, F.; Andersen, R.; Sondergaard, J. Qualitative description-The poor cousin of health research? BMC Med. Res. Methodol. 2009, 9, 52. [CrossRef] [PubMed]

21. Malterud, K.; Siersma, V.D.; Guassora, A.D. Sample size in qualitative interview studies: Guided by information power. Qual. Health Res. 2016, 26, 1753-1760. [CrossRef]

22. Braun, V.; Clarke, V. Using thematic analysis in psychology. Qual. Res. Psychol. 2006, 3, 77. [CrossRef]

23. Tayah, M.-J. Decent Work for Migrant Domestic Workers: Moving the Agenda Forward; International Labor Organisation: Geneva, Switzerland, 2016.

24. International Labour Organisation. Decent Work for Domestic Workers; International Labour Organisation: Geneva, Switzerland, 2010.

25. Hadjigeorgiou, N. Helping Those That Help Us: Challenges Faced by Foreign Domestic Workers in the Republic of Cyprus; Hellenic Observatory, European Institute UCL; PRIO Cyprus Centre: Nicosia, Cyprus, 2020. ISBN 978-82-343-0172-8. (Online).

26. Jayapalan, A.; Wong, L.P.; Aghamohammadi, N. A qualitative study to explore understanding and perception of sexual abuse among undergraduate students of different ethnicities. Women's Stud. Int. Forum 2018, 69, 26-32. [CrossRef]

27. Pavlou, V. Domestic work in EU Law: The relevance of EU Employment Law in challenging domestic workers' vulnerability. Eur. Law Rev. 2016, 41, 379-398.

28. Trimikliniotis, N. Racism and new migration in Cyprus: The racialisation of migrant workers. In Into the Margins: Exclusion and Migration in Southern Europe; Anthias, F., Lazarides, G., Eds.; Taylor\&Francis Group: Oxford, UK, 1999.

29. Hadjigeorgiou, N. Foreign Domestic Workers in Cyprus: The Unseen Impact of the Frozen Conflict; LSE: London, UK, 2021.

30. Zervidou, M. National Report: The case of Cyprus. In Integration of Female Migrant Domestic Workers: Strategies for Employment and Civic Participation; University of Nicosia Press: Nicosia, Cyprus, 2008.

31. Chang, K.A.; Groves, J.M. Neither "saints" nor "prostitutes": Sexual discourse in the Filipina domestic worker community in Hong Kong. Women's Stud. Int. Forum 2000, 23, 73-87. [CrossRef]

32. Thomson, M. Migrants on the Edge of Europe: Perspectives from Malta, Cyprus and Slovenia; Sussex Migration Working Paper no. 35; Sussex Centre for Migration Research: Brighton, UK, 2006.

33. Liang, L.-F. The making of an 'ideal' live-in migrant care worker: Recruiting, training, matching and disciplining. Ethn. Racial Stud. 2011, 34, 1815-1834. [CrossRef]

34. Panayiotopoulos, P. The globalisation of care: Filipina domestic workers and care for the elderly in Cyprus. Cap. Cl. 2005, 29, 99-133. [CrossRef]

35. Garcia-Moreno, C.; Watts, C. Violence against women: An urgent public health priority. Bull. World Health Organ. 2011, 89, 2. [CrossRef]

36. Robillard, C.; McLaughlin, J.; Cole, D.C.; Vasilevska, B.; Gendron, R. “Caught in the Same Webs"-Service Providers' Insights on Gender-Based and Structural Violence Among Female Temporary Foreign Workers in Canada. J. Int. Migr. Integr. 2018, 19, 583-606. [CrossRef]

37. Tong, A.; Sainsbury, P.; Craig, J. Consolidated criteria for reporting qualitative research (COREQ): A 32-item checklist for interviews and focus groups. Int. J. Qual. Health Care 2007, 19, 349-357. [CrossRef]

38. Gallotti, M.; Mertens, J. Promoting Integration for Migrant Domestic Workers in Europe: A Synthesis of Belgium, France, Italy and Spain; International Labour organization: Geneva, Switzerland, 2013.

39. Grown, C.; Gupta, G.; Pande, R. Taking action to improve women's health through gender equality and women's empowerment. Lancet 2005, 365, 541. [CrossRef] 